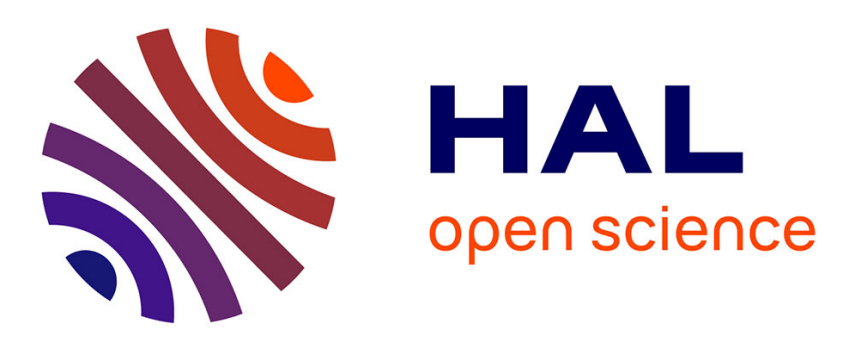

\title{
Development of a novel façade sandwich panel with low-density wood fibres core and wood-based panels as faces
}

José L. Fernandez-Cabo, Almudena Majano-Majano, Luis San-Salvador Ageo, Miguel Ávila-Nieto

\section{To cite this version:}

José L. Fernandez-Cabo, Almudena Majano-Majano, Luis San-Salvador Ageo, Miguel Ávila-Nieto. Development of a novel façade sandwich panel with low-density wood fibres core and wood-based panels as faces. European Journal of Wood and Wood Products, 2010, 69 (3), pp.459-470. 10.1007/s00107010-0468-0 . hal-00615330

\section{HAL Id: hal-00615330 https://hal.science/hal-00615330}

Submitted on 19 Aug 2011

HAL is a multi-disciplinary open access archive for the deposit and dissemination of scientific research documents, whether they are published or not. The documents may come from teaching and research institutions in France or abroad, or from public or private research centers.
L'archive ouverte pluridisciplinaire $\mathbf{H A L}$, est destinée au dépôt et à la diffusion de documents scientifiques de niveau recherche, publiés ou non, émanant des établissements d'enseignement et de recherche français ou étrangers, des laboratoires publics ou privés. 


\title{
Development of a novel façade sandwich panel with low-density wood fibres core and wood-based panels as faces
}

\author{
Entwicklung einer neuartigen Sandwich-Fassadenplatte aus einem Kern mit \\ niedrig verdichteten Holzfasern und Holzwerkstoffbeplankung
}

José L. Fernández-Cabo, M. Almudena Majano Majano, Luis San-Salvador Ageo, Miguel Ávila Nieto.

\section{ETS of Architecture, Structural Department, Technical University of Madrid.}

Avda. Juan de Herrera, 4

28040 Madrid, Spain

jose.fcabo@upm.es

\begin{abstract}
The paper explores, experimentally and theoretically, the possibility of producing a novel cladding sandwich panel comprised of a low-density wood fibre (WF) core and faces made of wood-based panels.

Tests on small specimens, using physical and optical devices, were performed for the basic mechanical characterization of WF. Shear modulus $(G)$ was the main target; and values for a range of nominal densities $(\rho)$ from 110 to $190 \mathrm{~kg} / \mathrm{m}^{3}$ were obtained.

Short term load tests on real scale WF sandwich (WFS) specimens of $3.2 \mathrm{~m}$ span were also performed. An initial simple analytical structural linear model, taking into account the shear deformation of the core, was used to evaluate the data obtaining a reasonable agreement.

The results show that WFSs are a viable solution at least for claddings; special care must be taken, however, in the selection of the face panels due to the influence of hygro-thermal changes. The line of work is especially attractive as WF is a natural and sustainable product.
\end{abstract}

Zusammenfassung. In diesem Artikel wird auf experimenteller und theoretischer Basis die Möglichkeit aufgezeigt, neuartige Fassadenelemente in Sandwichbauweise bestehend aus einem Kern mit niedrig verdichteten Holzfasern (WF) und einer Holzwerkstoffbeplankung herzustellen.

An kleinen Prüfkörpern wurden unter Verwendung von mechanischen und optischen Messverfahren die grundlegenden mechanischen Eigenschaften der WF bestimmt. Größte Bedeutung hatte dabei die Ermittlung des Schubmoduls $(G)$, und für WF mit einer nominellen Dichte $(\rho)$ von $110 \mathrm{~kg} / \mathrm{m}^{3}$ bis $190 \mathrm{~kg} / \mathrm{m}^{3}$ wurden Werte bestimmt.

Weiterhin wurden an WF-Sandwich Elementen (WFS) in Bauteilgröße mit einer Spannweite von $3.20 \mathrm{~m}$ Kurzzeitprüfungen durchgeführt. Ein einfaches lineares statisches Modell, das die Schubverformung des Kerns berücksichtigt, wurde für die Analyse des Tragverhaltens verwendet. Dieses Modell zeigte eine gute Übereinstimmung mit den Versuchsdaten.

Die Versuchsergebnisse belegen, dass WFS eine brauchbare Konstruktion für Fassaden darstellen, wobei jedoch der Einfluss von Temperatur und Feuchte bei der Auswahl der Beplankungen besonders beachtet werden muss. Hervorzuheben ist, dass mit den WF ein natürliches und nachhaltiges Material zur Verfügung steht. 


\section{INTRODUCTION}

\subsection{Aim of the work}

The development of new building materials and systems based on sustainable and ecological criteria is clearly a current challenge in the building construction field. The design of new claddings is a crucial issue. The development of novel sandwiches presents the advantage of coupling building physics and structural criteria.

Considering non-steady state situations, low density wood fibre (WF) panels also have an advantage over plastic foams and mineral wools. Thanks to their better thermal effusivity, they better stabilize indoor temperatures. As the weight is higher in relation to the alternative solutions in extruded polystyrene (XPS) or rock wool, the acoustic insulation is also increased, a relevant issue nowadays. The porosity of WF translates again into acoustic benefits. WF has of course clear advantages when sustainability criteria are considered.

Different nominal densities ( $\rho$ ) of WF ranging between 110 to $190 \mathrm{~kg} / \mathrm{m}^{3}$ were used in the tests. This variation of density hardly affects WF's thermal conductivity value, maintained around $0.04 \mathrm{~W} / \mathrm{mK}$; this insulation is in the same range as other existing foam, such as expanded polystyrene (EPS) and XPS. These data explain why the use of WF insulation in building construction is an increasing practice in Europe, especially in Germany and Austria.

\subsection{Current approaches for sustainable and high efficiency cladding panels}

The idea of a sandwich with a WF core (WFS) was also explored some years ago by a group at the Kyoto Univ. (Kawasaki et al. 1998, 2003, 2006; Kawasaki and Kawai 2006; Kawasaki 2006; Wada et al. 2003), proposing an optimum panel thickness of around $100 \mathrm{~mm}$, with a core density of $400 \mathrm{~kg} / \mathrm{m}^{3}$ (the range of $\rho$ studied varied from 320 to $480 \mathrm{~kg} / \mathrm{m}^{3}$ ).

The work here presented addressed the question on quite a different basis. First, Kawasaki et al. were in fact concerned about the in-plane shear stiffness, that is, the behaviour as a diaphragm. This can be relevant if the seismic forces are important, as is the case in Japan, but it is not an important variable in many countries in Europe. The present work is mainly focused on the use of sandwich panels in bending in response to wind loads. Second, and more important, a much lower density is used in the core, and thus higher insulation efficiency and lower costs are obtained.

There are other novel paths for developing new sustainable and high efficiency claddings. One trend is the use of natural composites. Dweib et al. (2004) and O'Donnell et al. (2004) have proposed a new double -I- sandwich panel for claddings with the flanges and web made of soybean oil resins and natural fibres. Nevertheless, the core does not contribute in the structure, and it is made of closed cell polyisocyanurate foam. 
A running European research project, entitled "Building of Tomorrow", is developing an over insulated light frame timber construction system using a sandwich with OSB and MDF boards at the inner and outer faces, respectively, and a thick additional insulation at the core made of TJI joists connecting the faces. The panel does not have any additional outer cladding, which is very interesting cost wise. The element can also bear compression loads thanks to the TJI joists in the core. The idea is being developed in joint effort by industries, led by Weissenseer Holz-System Bau (http://www.weissenseer.at/), and the Fachhochschule Kärnten, both from Austria.

As the solution here presented limits now the structural use of WFS for withstanding wind load, creep, a separate and unknown problem, is not a question at this state. The vertical self weight of the panel is carried by the outer faces, acting as two beams in their own plane. As the core is only made of WF, thermal bridges are avoided. Furthermore, the solution provides large freedom when it comes to architectural design, and the main timber structure can be kept dry and under visual control indoors.

\subsection{Mechanical parameters for the characterization of a WF versus the theoretical model}

The 3D characterization of low-density wood fibres is a current topic of research (Faessel et al. 2005; Poquillon et al. 2005; Pourdeyhimi et al. 2006; Badel et al. 2008; Stock 2008). Porous materials can have complex and unusual constitutive equations. Poisson's ratio can be close to zero or even positive. Fortunately, this value does not have a relevant influence if the WFS panel is working in a plane stress state, i.e., as a beam.

An important background on sandwich panels exists since the 1960's (Allen 1969). Much work was carried out in the 90's based on finite elements (Ha 1990), as well as on exact matrix formulations (Ha 1992, 1993). A very large amount of papers have addressed the topic in the last decade, and in many different ways. The International Council for Research and Innovation in Building and Construction (CIB) has published a good general overview (Davis 2001) that includes general matrix formulations and solved formulae for typical beams. The only mechanical parameters required for the materials in the case of the typical hypothesis for a linear model of sandwich beams (Ha 1990) are the shear modulus $(G)$ of the core and the bending stiffness $(E I)$ of both faces. Real scale tests confirmed that the linear approach can be used, and therefore only these two material parameters were experimentally assessed. Further details are given in section 2.5.

The paper reports the experimental and theoretical work carried out for studying the viability of producing a WFS for a novel cladding. In the initial part of the experimental work, the shear modulus $(G)$ values of the WF for a range of $\rho$ from 110 to $190 \mathrm{~kg} / \mathrm{m}^{3}$ were obtained. The bending stiffness of the timber faces were also measured for checking the nominal data. Real scale tests, simulating the wind load, were developed in the second part of the experimental work. The empirical data were quasi-linear, and therefore the results were compared with a simple theoretical linear model. As the experimental and theoretical results agreed reasonably well, a simple parametrical study, including a basic study of the 
influence of hygro-thermal variations, was developed in order to complement the conclusions.

\section{MATERIALS AND METHODS}

\subsection{Materials and production process of WFS}

WFS specimens were industrially assembled by the company Dold Holzwerke. A total of eleven WFS were finally tested. The faces of the WFS were made of oriented strand boards (OSB) $15 \mathrm{~mm}$ thick, and the core was made with GUTEX ${ }^{\circledR}$ WF of four different $\rho: 110,130,150$ and $190 \mathrm{~kg} / \mathrm{m}^{3}$. These densities approximately correspond to the following commercial names: Gutex Thermosafe homogeny, Gutex Thermosafe-wd, Gutex Thermowall, Gutex Ultratherm (see Gutex datasheets for a complete definition of each product according to EN 13171:2001; a new version is under development: prEN 13171:2008).).

The nominal depth of the core is $120 \mathrm{~mm}$ (the maximum single-piece depth available at that time). Actual depths varied from 110 to $120 \mathrm{~mm}$ due to the pressure applied during the gluing process. A WF density of $170 \mathrm{~kg} / \mathrm{m}^{3}$ was not available, and this motivated the substantial step between core densities of 150 and $190 \mathrm{~kg} / \mathrm{m}^{3}$.

The WFS were produced with a total length of $4500 \mathrm{~mm}$, but the final total span tested was $3400 \mathrm{~mm} .1100 \mathrm{~mm}$ pieces were thus obtained for performing small scale shear tests. This procedure of obtaining both small and real scale samples from the same production elements reduces material uncertainties. The gluing machine used spreads glue strips along the panel, obtaining a real glued surface that is approximately half of the full contact surface.

\subsection{Set up of small scale shear tests of WF}

A setup (Fig. 1) similar to the timber standard NT BUILD 378: 1991, considered to be valid for this material, was chosen for the tests. Previous tests are required for determining the breaking load, $\mathrm{F}_{\mathrm{v}, \max }$, obtained for a total testing time of between 3 and 5 minutes. The $\mathrm{G}$ value is calculated according to a linear relationship between $0.1 \cdot \mathrm{F}_{\mathrm{v}, \max }$ and $0.4 \cdot \mathrm{F}_{\mathrm{v}, \max }$. Displacement control was used, with a rate of $0.25 \mathrm{~mm}$ per minute. A similar set up is sometimes used for foams when considering tensile forces. Nonetheless, the compression arrangement is more appropriate for testing real WFS pieces, as the OSB faces are easily compressed but not so easily tensioned.

The G value was measured using two kinds of devices. The first one was LVDT's, located on the OSB faces. The upper and lower faces have the same rotation, $\theta$, in each section (Fig. 2). Due to this, the LVDT of the set up (Fig. 1) measures the whole slip, $\delta$, between the faces, including any possible local slip at the OSB-WF contact surface (whether the variation across the WF section is linear or not). The $G$ value obtained can then be called -global-, as it takes into consideration the total slip and not its governing law. The second measuring procedure involved optical measurements, using ARAMIS $®$ system, with 3D capabilities, and a resolution of 2 mega pixels. A net of crossed lines drawn on the specimen with a marker pen was used as a pattern. 


\subsection{Bending tests on OSB panels}

Three WFS damaged at the core during transport (those of lower densities) were used for testing the EI value of the OSB panels alone. A total of four tests were done. Two sets of tests were carried out using a three point setup and a further two sets using a four point setup. The reason for using two different setups was to try to verify the homogeneity of the material. The procedure was similar to EN310:1993 (which calculates the Young modulus, not EI as a single value). The span was $1 \mathrm{~m}$ and the width was the same as that of the original WFS, i.e. approximately $475 \mathrm{~mm}$.

\subsection{Setup of real scale test of WFS}

Bending tests were all carried out for a free span of $3200 \mathrm{~mm}$, using $3400 \mathrm{~mm}$ long specimens in a six-point type arrangement (Fig. 3). The technical report EOTA TR002 (EOTA. 2000, Test methods for Light Composite Wood-based Beams and Columns), uses a four-point arrangement. The six-point arrangement was preferred here, at this preliminary stage, for better checking the theoretical model (the bending moment is almost exact to that generated by a uniformly distributed load). Small neoprene strips release the horizontal movements both at one of the supports and at some of the timber pieces used for transferring the vertical load. Controlled displacement, with a rate of $1 \mathrm{~mm}$ per minute, was chosen. Because, as said before, WF panel thickness of $120 \mathrm{~mm}$ was the largest available, a free span of $3.2 \mathrm{~m}$ was chosen in order to achieve a standard slenderness ratio $(3200 /(15+120+15)=21,3)$ for a façade panel.

Two groups of tests were performed: the first, referred to as partially instrumented (P-IT), for $\rho$ of 110 and $130 \mathrm{~kg} / \mathrm{m}^{3}$, only measured load versus deflection at midspan; and the second set, referred to as globally instrumented (G-IT), for $\rho$ of 150 and $190 \mathrm{~kg} / \mathrm{m}^{3}$, was performed with a more complete instrumentation and therefore capable of achieving a more refined calibration. The specimens of $\rho=110 \mathrm{~kg} / \mathrm{m}^{3}$ turned out to be too weak for a span of $3.2 \mathrm{~m}$. They were not easy to test, and this is the main reason why the research quickly focused on the higher densities $\left(150\right.$ and $\left.190 \mathrm{~kg} / \mathrm{m}^{3}\right)$.

The last group, G-IT, consisted of three further sets of tests done on the same WFS specimen. Set- 1 and set- 2 were carried out without breaking the sandwich; they stopped when the maximum deflection reached $15 \mathrm{~mm}$ for $\rho=190 \mathrm{~kg} / \mathrm{m}^{3}$ and $10 \mathrm{~mm}$ for $\rho=150 \mathrm{~kg} / \mathrm{m}^{3}$. Set- 2 was only added to check vertical movements of the core over the supports. None of the beams broke at set-2. For set-3 the load was increased until fracture occurred.

\subsection{Structural model for bending}

A simple linear model, based on Annex B of Eurocode 5 (EC-5, Annex B) (CEN1995, 2003), was mainly used, although other sources were also compared, as will be seen. The proposed WFS clearly belong to the field of timber engineering, and therefore EC-5 was the initial reference. The use of this standard would help in the application of ETAG-016 (part 3) (EOTA 2005). EC-5 model is a linearized model: the stiffness of the connection is linearized using equivalent secant values. The same approach will be used here. 
The assumptions are: i) linear-elastic constitutive equations, ii) the axial stiffness of the core is neglected, iii) the curvature at both flanges is the same, iv) shear deformation is considered only at the core, not at the flanges, v) the vertical deflection of the two flanges is the same (the kinematic model is shown in Fig. $2)$. Three degrees of freedom per section are then considered: deflection $(v)$, rotation $(\theta)$ and slip of the core $(\delta)$; which is the typical assumption for sandwich beams with a linear behaviour.

The use of EC-5 (Fig. 4) just implies considering section -2- with zero area, but maintaining the slip caused by the dowel connections at the top and at the bottom of this section -2- (Fig. 5).

According to EC-5, being $Q$ the shear force at the dowel, $\delta$ the total slip of the dowel due to $Q$, and $K_{\text {ser }}$ the stiffness of the dowel connection:

$$
Q=K_{\text {ser }} \cdot \delta
$$

The Gamma method, used in EC-5, uses the unitary stiffness $k_{\text {unt }}$ of the whole connexion as a key variable (in fact, $k_{\mathrm{i}}$ is used instead of $k_{\text {unt,i }}$, but the latter is here preferred in order to highlight the nature of this parameter):

$$
q=Q / s=K_{\text {ser }} / s \cdot \delta
$$

where $s$ is the separation between dowels and $q$ the distributed shear force, then:

$$
\begin{array}{r}
k_{\mathrm{unt}}=\left(K_{\mathrm{ser}} / s\right) \\
q=k_{\mathrm{unt}} \cdot \delta
\end{array}
$$

If the core is considered as two equal local connections (Figs.4 and 5), each of these ones ( $\mathrm{i}=1$ and 3 ) would have a local unitary stiffness, $k_{u n t, i}=k_{u n t, 1}=k_{u n t, 3}$ (for half of the depth, the slip is half, and thus the stiffness is double):

$$
\begin{aligned}
& k_{u n t, i}=2 \cdot k_{u n t} \\
& q=k_{\mathrm{unt}, \mathrm{i}} \cdot \delta / 2
\end{aligned}
$$

Considering now a sandwich section, and being $\tau$ the shear stress and $b$ the width of the sandwich beam (at Fig. $4, b=b_{1}=b_{2}=b_{3}$ ):

$$
q=Q / s=(\tau \cdot b \cdot s) / s=\tau \cdot b
$$

and again, with the hypothesis of elastic-linear constitutive equations, using an equivalent shear modulus and comparing with Eq. (4): 
EJWWP468_source

$$
q=\tau \cdot b=G_{\mathrm{sec}} \cdot \gamma \cdot b=G_{\mathrm{sec}} \cdot b \cdot \delta / h_{2}=\underbrace{G_{\mathrm{sec}} \cdot b / h_{2}}_{k_{\mathrm{unt}}} \cdot \delta
$$

Then, according to Eq.(4) and (5)

$$
k_{u n t, i}=k_{u n t, I}=k_{u n t, 3}=2 \cdot k_{u n t}=2 \cdot G_{\mathrm{sec}} \cdot b / h_{2}
$$

The equivalent bending stiffness of the sandwich beam for a simply supported beam with uniformly distributed load, according to the gamma method of EC-5, is ( $\gamma^{*}$ is used instead of $\gamma$, as in EC-5 Annex B, as the latter is normally reserved for the engineering shear strain):

$$
\begin{gathered}
E I_{\text {eff }}=\sum_{i=1,3}\left(E_{i} \cdot I_{i}+\gamma_{i}^{*} \cdot E_{i} \cdot A_{i} \cdot a_{i}^{2}\right) \quad(10) \\
\gamma^{*}{ }_{i}=\frac{1}{1+\frac{\pi^{2} \cdot E_{i} \cdot A_{i}}{l^{2}} \cdot\left(\frac{1}{k_{\text {unt,i }}}\right)}=\frac{1}{1+\frac{\pi^{2} \cdot E_{i} \cdot A_{i}}{l^{2}} \cdot\left(\frac{h_{2}}{2 \cdot G_{\text {sec }} \cdot b}\right)}
\end{gathered}
$$

where (Fig. 4) $A_{i}$ is the area of the individual part -i- (1 and 3), $l$ the span, and $a_{i}$ the distance from the center of gravity of the whole sandwich to the center of gravity of the individual part -i-. The value of $a_{i}$ can be, in general, calculated using the EC-5 formulation based on the homogenization of the section.

The shear stresses at the core are (as the core does not bear normal stress, the shear stress across the core is constant):

$$
\tau_{\text {core }, i}=\frac{\gamma_{i}^{*} \cdot E_{i} \cdot A_{i} \cdot a_{i} \cdot V}{E I_{e f f} \cdot b}
$$

where $V$ is the shear force, $b$ the width of the core, i.e. the width of the sandwich, and $-\mathrm{i}-1$ or 3 .

The EC-5 model was compared with the model proposed by Davis (2001) (see Chapter 9, "Principles of Structural Behaviour") for panels with flat or lightly profiled faces, and the results are almost equal (the assumptions are the same). The theoretical model shall be referred to as EC-5 model, despite Davis' formulae were also used for checking values other than deflection.

For the sake of simplicity, the overall bending moment in a section, $M_{T}(x)$, can be divided into two local bending moments at the flanges, $m_{1}(x)$ and $m_{3}(x)$, plus the bending moment $N(x) \cdot z, N(x)$ being the axial load located at the centers of gravity of the flanges, separated a distance $z=a_{1}+a_{3}$ (Fig. 4).

$$
M_{T}(x)=N(x) \cdot z+m_{1}(x)+m_{3}(x)
$$


The slip $\delta$ can be obtained from Eq. (6) and (9), considering that (see FernandezCabo et al. 2008 for a more detailed explanation and the expression of $N(x)$ for a uniform and a cosine-shaped load; the formulation for a mixed beam, with a gap between the two pieces, leads to the same differential equation implicit in the EC5 model):

$$
\begin{aligned}
& q=\frac{d N(x)}{d x} \\
& \delta(x)=\frac{h_{2}}{G_{\mathrm{sec}} \cdot b} \cdot \frac{d N(x)}{d x}
\end{aligned}
$$

Once $N(x)$ is obtained, the analysis is in fact fully solved, as $\left(m_{1}(x)+m_{3}(x)\right)$ can be calculated using Eq. (13), and these local moments are distributed proportionally to the relative bending stiffness of the flanges; half and half in this case. The behavior of each flange follows now the classical laws of strength of materials. See e.g. Kreuzinger (1995) for additional explanations of the basis of EC-5.

\subsection{Structural model for the analysis of the maximum deflection under the variation of equilibrium moisture content (EMC)}

The variation of EMC, along the span and across the sections, of an outdoor panel is a dynamic and complex process. At this preliminary stage, a ballpark number is given for demonstrating the possible deep influence of this issue in a simply supported beam.

Let $\alpha$ be the longitudinal strain (\%) of one face per 1\% of variation of EMC. For the sake of simplicity it is supposed, that the indoor environment is constant; therefore $\alpha$ is generated by variation in the outer face only. The problem can be bound around $0.005 \% / \% \leq \alpha \leq 0.02 \% / \%$. The first value is typical of normal wood-based panels, such as OSB, and the second corresponds to a thermal treated timber (TMT) cladding board with all planks in the same direction. An ASE (antishrinking efficiency) index of effectiveness is commonly used when dealing with hygro-thermal stability. It quantifies the improvement of dimensional stability and reflects the difference between the swelling of the treated and untreated wood. The swelling is calculated between the dry state and the relative humidity under study. The overall ASE ranges from a minimum of approximately $(10 \%)$ to roughly $50 \%$ (Yildiz 2002), depending on the increase of the temperature and time of treatment, and it was found to be independent of the relative humidity (Tjeerdsma et al. 1998a, 1998b). The typical value for normal timber, in the longitudinal direction, is approximately $\alpha \cong 0.01 \% / \%$. The lower limit, $\alpha=0.005 \% / \%$, associated with a TMT board or similar, comes then from assuming an ASE value of 0.5 .

Let $\beta$ be the maximum variation of EMC between flanges, or the variation at the outer face considering the inner face to remain steady. For the parametrical study, the problem is bound between $5 \% \leq \beta \leq 15 \%$; even though it must be remembered that the upper limit can vary widely from one problem to another.

The local curvature, $\kappa$, for specific $\alpha$ and $\beta$ values is: 
EJWWP468_source

$$
\kappa=\frac{\alpha \cdot \beta}{100 \cdot z}
$$

where $z$ is the distance from the centre of gravity to the two flanges.

The maximum deflection $v_{\max }$ for a simply supported beam with $\operatorname{span} L$, due to a $\kappa$ defined in Eq.(16), and according to the well known Mohr's theorem, is:

$$
v_{\max }=\kappa \cdot \frac{L}{2} \cdot \frac{L}{4}
$$

And then the maximum relative deflection, for a simple supported beam, can be obtained using:

$$
\frac{v_{\max }}{L}=\frac{\alpha \cdot \beta}{100 \cdot z} \cdot \frac{L}{8}
$$

\section{RESULTS}

\subsection{Shear modulus of the WF core}

The optical measurement device was able to reflect the whole slip across five sections of the WF cores separated around 20mm (Fig. 6). The non linear law reflects the variation of density across the section. The label used for a specific small scale (shear) test, SST, e.g., SST-150-4-ak means: shear test -a- made from a piece of sandwich cut from beam number 4 , which has a $\rho=150 \mathrm{~kg} / \mathrm{m}^{3}$. As there are no steps in the plot, it was confirmed that no noticeable local slip took place at the OSB-WF interface. Similar values were obtained for the other three densities. It is worth mentioning that the bigger the density, the smaller the variation of density across the section.

Considering the full slip between OSB faces, $G$ is a quasi-linear parameter (Fig. 7). The linearized $G_{\text {sec }}$ values adopted, calibrated using the results of the real scale tests are shown in Table 1.

\subsection{Bending stiffness El of the OSB panels}

The EI value was obtained specifically for checking the nominal EI value of the OSB panels produced by Kronofrance, given to be $E I=1.9125 \mathrm{kNm}^{2} / \mathrm{m}$. An average value of $E I=2.29 \mathrm{kNm}^{2} / \mathrm{m}$, derived from the test, was used in the calculations.

\subsection{Empirical data versus analytical model: deflection}

The following figures (Fig. 8a to 8d) plot the total force $(\mathrm{kN})$ versus the deflection (dotted lines) at midspan recorded in the tests (Fig. 3, section D) and the linearized model (continuous black line) for the whole range of densities. The name given to a specific test, e.g., P-IT-110-6 means: P-IT $\equiv$ partial instrumented 
test (G-IT $\equiv$ global instrumented test), $110 \equiv \rho=110 \mathrm{~kg} / \mathrm{m}^{3}, 6 \equiv$ reference number of the specimen.

Table 1 also summarizes the values of shear secant strength, $f_{\mathrm{v}, \mathrm{sec}}$, for the four densities analysed. The values were derived from the breaking load of the real scale test together with the theoretical model.

The comparison between the empirical data (Fig. 9a), using a linear regression plot (dashed line) and a typical curve (dotted lines), and the theoretical EC-5 model (continuous line), for $\rho=150$ and $190 \mathrm{~kg} / \mathrm{m}^{3}$, was also carried out at sections $\mathrm{B}$ and $\mathrm{C}$ (see Fig. 3).

\subsection{Empirical data versus analytical model: total slip at the core}

Fig. $9 \mathrm{~b}$ shows the comparison between the empirical data, using a linear regression plot (dashed line) and a typical curve (dotted lines), and the theoretical EC-5 (continuous line), for $\rho=150$ and $190 \mathrm{~kg} / \mathrm{m}^{3}$, at sections B and C (see Fig. 3), where the shear force is equal. The point selected in the linear model for the comparison was the middle point between $\mathrm{B}$ and $\mathrm{C}$, as the shear force at this point in the model is equal to the shear force in the test at B and C.

\subsection{Empirical data versus analytical model: rotations}

Figs. $10 \mathrm{a}$ and $10 \mathrm{~b}$ show the comparison between the empirical data, using a linear regression plot (dashed line) and a typical curve (dotted lines), and the theoretical EC-5 (continuous line), for $\rho=150$ and $190 \mathrm{~kg} / \mathrm{m}^{3}$, at sections B and C (see Fig. 3) respectively.

\subsection{Failure model}

The failure of the panels presented a recurring pattern, allowing the formulation of a basic failure mode. All beams except one collapsed with the same and expected failure mode, like e.g. at P-IT-110-6, shown in Fig. 11. The failure is due to shear stress and starts at the WF-OSB contact surface (where the gluing process reduces the effective section) over one support (where the shear stresses are maximum); the cracking then runs towards the centre of the beam. However, the failure surface is not a perfect plane and, even though the origin is at the glued interface, it can present some small irregularities across the section. Failure is brittle, also reflected by the plots of total load versus midspan deflection (Fig. 8a to 8d). Only one specimen, G-IT-190-18, failed in an unexpected way. The failure was also due to shear stress, but wasn't located at the glued interface. The reason is currently unclear; one possibility could be material irregularities. The OSB flanges did not break in any of the tests.

A failure mode considering only the maximum shear stress seems to lead to a reasonable approximation at this stage. According to this, the overall deflection and the shear stress are the two limiting parameters in the design. 


\subsection{Parametrical study for wind load}

Once the linear model was proved to fit reasonably well with the empirical data, a parametrical study was developed in order to explore the practical field of application of the proposed solution. According to the last section, two critical points were considered: a) for serviceability limit state (SLS), the midspan deflection; b) for ultimate limit state (ULS), the shear strength near the supports. Using the data from Table 1 and the model described in section 2.5, Table 2 was constructed: a typical wind load of $1.2 \mathrm{kN} / \mathrm{m}^{2}$ and a depth of the core ranging from $120 \mathrm{~mm}$ to $240 \mathrm{~mm}$. The thickness of the core is mostly governed by the thermal requirements of the cladding. For German climate or similar, which was the original target of this study, calculations based on thermal conditions lead to $U$ values between 0.15 to $0.2\left(\mathrm{~W} /\left(\mathrm{m}^{2} \mathrm{~K}\right)\right)$ which can be translated into an insulation depth of around 250 to $300 \mathrm{~mm}$. Values in warmer regions can go down to around $120 \mathrm{~mm}$ (Kahlert 2008).

The maximum span, for SLS and ULS, can be obtained from Table 2. SLS varies according to the standards and the construction system; a value from 1/300 to $1 / 500$ is typical. Table 2 was expanded to include up to $1 / 800$ for the possibility of increasing the global safety factor in cases where the deflection due to the hygrothermal changes is relevant (see section 3.8).

The viability of a solution can be determined by looking at its global safety factor, which is obtained by dividing the maximum span in ULS to the span in SLS. For example, considering $\rho=150 \mathrm{~kg} / \mathrm{m}^{3}$, a total depth of $15+240+15 \mathrm{~mm}$, and a SLS of $1 / 300$, the global safety factor is $(23 \mathrm{~m} / 6.46 \mathrm{~m})=3.56$. As can be checked, in the typical range from $1 / 300$ to $1 / 500$, and $\rho=150$ to $190 \mathrm{~kg} / \mathrm{m}^{3}$, the global safety factor goes from a minimum of 2.97 for the core of $120 \mathrm{~mm}$ and SLS of $1 / 300$ to a maximum of 7.29 for the core of 240 and SLS of 1/500. For a SLS of 1/800, the maximum reaches 8.87 .

\subsection{Influence of the moisture content variation}

According to the assumptions given in section 2.6, Table 3 bounds the upper and lower limits of relative deflection due to hygro-thermal changes. The table shows that, if the outdoor boards were not properly selected, this deflection could be higher than that due to wind loads.

\section{DISCUSSION}

The use of wood-based panels responds to the general search for a sustainable and environmentally friendly product. Even though there is a broad range of boards of this kind, their thickness is similar in all cases, and therefore their EI would not change substantially from one to another. The inner face can be designed with OSB because it is cost effective, the hazard class is null and in some environments it may even work without an extra vapour barrier. If an outdoor TMT or medium density fibre (MDF) board was finally used, the deflection due to hygro-thermal changes could be assumed. Other wood-based panels, like e.g. wood-cement boards, would also be of great interest. 
It is worth checking the $\gamma^{*}{ }_{i}$ values (Eq. 11) of the real scale tested beams, for the different densities considered (Table 4). As it is known, $\gamma^{*}{ }_{i}$ represents the reduction of the width of the WFS in order to get the equivalent current bending stiffness A value of $\gamma^{*}{ }_{i}=1$ means zero slip in the core, obtaining, therefore, a section with a maximum bending efficiency. For a density lower than $150 \mathrm{~kg} / \mathrm{m}^{3}$, the reduction is too high, and the sandwich efficiency is greatly reduced. This confirms that the range of viable core densities lies between 150 and $190 \mathrm{~kg} / \mathrm{m}^{3}$.

The shear capacity is halved in relation to the possible maximum value due to the discontinuity of the glue strips. This means that, according to the failure mode shown in section 3.6, the global safety factor could be doubled if the gluing surface was complete.

Both the use of TMT and WF as structural materials fit with difficulty into the scope of existing structural European standards. CE marking is now not compulsory for WFS, but can be addressed using ETAG 016 (part 3). The problem of lacking adequate EN harmonized standards for TMT and WF could thus be avoided.

\section{CONCLUSION}

The use of WFS for claddings made of WF with $\rho$ ranging between 110 and 190 $\mathrm{kg} / \mathrm{m}^{3}$ was explored from a structural point of view. The WFS were designed to withstand their self weight and the wind load, and thus avoid the question of creep.

Small scale tests showed that density across a WF section is not constant. Optical measures showed that the variations between sections are negligible, and so a global and unique $\mathrm{G}$ value can be assumed for the overall WF section. The material behaviour of the WF lightly differs from the lower $\rho\left(110 \mathrm{~kg} / \mathrm{m}^{3}\right)$ to the upper ones $\left(190 \mathrm{~kg} / \mathrm{m}^{3}\right)$. A quasi-linear behaviour was observed for all the densities, recording that the higher the $\rho$, the more clear the linear behaviour. $G_{\text {sec }}$ values were obtained for the whole range of densities, based on these small scale tests and calibrated with the real scale tests.

Real scale tests confirmed the quasi-linear behaviour of the WF core, and therefore, of the beam itself. The recorded deflections, rotations and slips at the core were compared with the linear theoretical model. The results agreed reasonably well. Small differences exist. These can be explained by the slight difference between the setup load (six point load arrangement) and the load of the theoretical model (uniformly distributed, or, at EC-5, a cosine-shape load). A further explanation is the use of a linear model for a relation that is not totally linear.

A parametrical study, using the mentioned linearized model, was carried out for the wind load. The results show that WFS is a viable solution for $\rho$ ranging between 150 and $190 \mathrm{~kg} / \mathrm{m}^{3}$, as the SLS can be fulfilled with a global safety factor between 3 and 8 . The hygro-thermal movements do not introduce any remarkable 
changes to these conclusions if panels, e.g. TMT boards, with high hygro-thermal stability, are used for the outdoor flange.

This is only a preliminary study. More detailed investigations will be necessary for obtaining a commercial product.

\section{ACKNOWLEDGEMENTS}

The results presented were developed within the IP-SME project HOLIWOOD (Holistic implementation of European thermal treated hard wood in the sector of construction industry and noise protection by sustainable, knowledge-based and value added products). This project is being carried out with financial support from the European Community within the Sixth Framework Program (NMP2-CT-2005-IP 011799-2). We would like to thank the support of the German companies Holzfaserplattenwerk H. Henselmann and Dold Holzwerke for supplying and mounting the WFS. We would also like to thank for the support from GOM (Optical Measurement Techniques), and its filial Spanish company, METRONIC, and particularly to Stefan Hoheisel, for facilitating the use of the ARAMIS system. This publication reflects the authors view. The European Community and the mentioned companies are not liable for any use that may be made of the information contained therein.

\section{REFERENCES}

ARAMIS® system. GOM mbH, Mittelweg 7-8, 38106 Braunschweig, Germany. www.gom.com

Allen G, Howard (1969). Analysis and design of structural sandwich panels. Pergamon press. Oxford.

Badel E, Delisee C, Lux JSource. (2008) 3D structural characterisation, deformation measurements and assessment of low-density wood fibreboard under compression: The use of Xray microtomography. Composites Science and Technology 68 (7-8): 1654-1663.

Comité Européen de Normalisation (CEN) (1995) Eurocode 5 - Design of timber structures - Part 1-1: General rules and rules for buildings. ENV 1995-1-1. Bruxelles, Belgium.

Comité Européen de Normalisation (CEN). (2003) Eurocode 5 - Design of timber structures - Part 1-1: General rules and rules for buildings. prENV 1995-1-1. Bruxelles, Belgium.

Comité Européen de Normalisation (CEN/TC 88) (2008) prEN 13171:2008. Thermal insulating products for buildings - Factory made wood fibre (WF) products Specification.

Dold Holzwerke GmbH. Talstraße 9 D-79256 Buchenbach/Schwarzwald; Germany. www.doldholz.de/

Dweib MA, Hu B, O'Donnell A, Shenton HW, Wool RP (2004) All natural composite sandwich beams for structural applications. Composite Structures 63 (2):147-157.

Davis JM (Edr.) (2001) Lightweight sandwich construction. Blackwell Science.

Faessel M, Delisee C, Bos F, Castéra P (2005) 3D Modelling of random cellulosic fibrous networks based on X-ray tomography and image analysis. Composites science and technology 65 (13): 1931-1940.

Fernández-Cabo JL, Fernández-Lavandera J, Ávila-Jalvo JM (2008) Wood-concrete and woodwood mixed beams: Rational basis for selecting connections. Journal of Structural EngineeringASCE 134 (3): 440-447. 
GUTEX® GUTEX Holzfaserplattenwerk H. Henselmann GmbH + Co KG, Gutenburg 5, D-79761 Waldshut-Tiengen. Germany. www.gutex.de/.

Ha KH (1990) Finite-element analysis of sandwich plates: an overview. Computers \& Structures 37 (4): 397-403.

Ha KH (1992) Exact analysis of bending and overall buckling of sandwich beam systems. Computers \& Structures 45 (1):31-40.

Ha KH (1993) Stiffness matrix for exact solutions of sandwich beam and frame systems. Journal of Structural Engineering-ASCE 119 (4): 1150-1167.

Kawasaki T, Zhang M, Kawai S (1998) Manufacture and properties of ultra-low-density fibreboard. J. Wood Sci. 44:354-360.

Kawasaki T, Hwang K, Komatsu K et al (2003) In-plane shear properties of the wood-based sandwich panel as a small shear wall evaluated by the shear test method using tie-rods. J. Wood Sci. 49 (3): 199-209 2003.

Kawasaki T (2006) Wood-Based Sandwich Panel with Low-Density Fiberboard for use as Structural Insulated Wall and Floor. Ph D for Graduate School of Agriculture. Research Institute for Sustainable Human sphere Kyoto University.

Kawasaki T, Kawai S (2006) Thermal insulation properties of wood-based sandwich panel for use as structural insulated walls and floors. J. Wood Sci. 52 (1): 75-83.

Kawasaki T, Zhang M, Wang Q, Komatsu K, Kawai S (2006) Elastic moduli and stiffness optimization in four-point bending of wood-based sandwich panel for use as structural insulated walls and floors. J. Wood Sci. 52 (4): 302-310.

Kahlert C (2008) Ein rationaler Ansatz für die Definition des Passivhauses bei gewerblicher Nutzung. Proceedings of Pasivní Domy, 2008, p. 351-356, 30.-31 Oct 2008 Brno, CZ, Jan Barta \& Juraj Hazucha Editors, Centrum Pasivního Domu 2008.

Kreuzinger H (1995) Lecture B11. Mechanically joined beams and colums. STEP 1. Timber Engineering. Centrum Hout, The Netherlands, B11/1-8.

NT BUILD 378:1991. Timber in structural sizes: determination of shear strength and shear modulus parallel to the grain. NORDTEST.

O'Donnell A, Dweib MA, Wool RP (2004) Natural fiber composites with plant oil-based resin. Composites Science and Technology 64 (9):1135-1145.

EOTA: Organisation for Technical Approvals. Ed. February 2005. ETAG-016. Self-supporting composite lightweight panels. PART 3:Specific aspects relating to Self-supporting composite lightweight panels for use in external walls and claddings.

Poquillon D, Viguier B, Andrieu E (2005) Experimental data about mechanical behaviour during compression tests for various matted fibres. Journal of materials science 40 (22): 5963-5970 NOV 2005 .

Pourdeyhimi B, Maze B, Tafreshi HV (2006) Simulation and analysis of unbonded nonwoven fibrous structures. Journal of engineered fibers and fabrics 1 (2): 47-65 2006

Stock SR (2008) Recent advances in X-ray microtomography applied to materials. International materials reviews 53 (3): 129-181.

Tjeerdsma B, Boonstra M, Pizzi A, Tekely P, Militz H (1998a) Characterisation of thermally modified wood: molecular reasons for wood performance improvement. Holz Roh-Werkst 56:149-153 


\section{EJWWP468_source}

Tjeerdsma B, Boonstra M,,Militz, H (1998b). “Thermal modification of non-durable wood species. Part 2. Improved wood properties of thermally treated wood," In: International Research Group Wood Preservation, Document no. IRG/WP 98-40124.

Wada A, Kawasaki T, Minoda Y, Kataoka A, Tashiro S, Fukuda H (2003) A method to measure shearing modulus of the foamed core for sandwich plates. Composite Structures 60: 385-390

Yildiz, S (2002). "Effects of heat treatment on water repellence and anti-swelling efficiency of beech wood," In: International Research Group Wood Preservation, Section 4-Processes, $\mathrm{N}^{\mathrm{o}}$ IRG/WP 02-40223 


\section{FIGURE LEGEND}

Fig. 1 Setup of the shear test similar to NT BUILD 378:1991

Abb. 1 Anordnung des Schubversuchs in Anlehnung an NT BUILD 378:1991

Fig. 2 Degrees of freedom for the basic structural model: deflection $(v)$, rotation $(\theta)$, and slip deformation of the core $(\delta)$.

Abb. 2 Freiheitsgrade für das grundlegende statische Modell: Durchbiegung $(v)$, Rotation $(\theta)$, and Schubverformung des Kerns $(\delta)$.

Fig. 3 General setup and reference sections (only the instrumented half of the beam is shown).

Abb. 3 Versuchsanordnung und Referenzabschnitte (dargestellt ist nur eine Hälfte des Balkens).

Fig. 4 EC-5, annex B. One of the reference timbers mixed beams.

Abb. 4 EC-5, Annex B. Zusammengesetzter Träger als Referenzträger.

Fig. 5 Conversion of $\mathrm{G}$ into $\mathrm{K}_{\text {ser }}$

Abb. 5 Umwandlung von $\mathrm{G}$ in $\mathrm{K}_{\text {ser }}$

Fig. 6 Shear slip displacement (mm) across the WF section (mm) for three different nominal densities. The different curves correspond to five sections, at a distance of around $20 \mathrm{~mm}$ from each other, in test SST_150_4-a, $\rho_{\text {nom }}=150 \mathrm{~kg} / \mathrm{m}^{3}$, at $4.0 \mathrm{kN}$ load.

Abb. 6 Schubverformung $(\mathrm{mm})$ des WF-Abschnitts $(\mathrm{mm})$ bei drei verschiedenen nominellen Dichten Die Kurven entsprechen den 5 Abschnitten mit einem Abstand von jeweils ca. $20 \mathrm{~mm}$ voneinander, beim Versuch SST_150_4, $\rho_{\text {nom }}=150 \mathrm{~kg} / \mathrm{m}^{3}$, und einer Last von $4,0 \mathrm{kN}$.

Fig. 7 Shear stress $\left(\mathrm{N} / \mathrm{mm}^{2}\right)$ versus slip at the core using LVDT's for shear small test (SST) on a piece with nominal density of $\rho_{\text {nom }}=150 \mathrm{~kg} / \mathrm{m}^{3}$.

Abb. 7 Schubspannung $\left(\mathrm{N} / \mathrm{mm}^{2}\right)$ in Abhängigkeit der Schubverformung im Kern auf Basis der LVDT Messungen an einem Prüfkörper nach Abb. 1 mit einer nominellen Dichte von $\rho_{\text {nom }}=150$ $\mathrm{kg} / \mathrm{m}^{3}$

Fig. 8 Total load $(\mathrm{kN})$ versus midspan deflection $(\mathrm{mm})$ for real scale test results and EC-5 model with $\rho_{\text {nom }}=110 \mathrm{~kg} / \mathrm{m}^{3}, G_{\text {sec }}=0.7 \mathrm{~N} / \mathrm{mm}^{2}$ (a); $\rho_{\text {nom }}=130 \mathrm{~kg} / \mathrm{m}^{3}, G_{\text {sec }}=1.06 \mathrm{~N} / \mathrm{mm}^{2}$ (b); $\rho_{\text {nom }}=150 \mathrm{~kg} / \mathrm{m}^{3}$, $\mathrm{G}_{\mathrm{sec}}=3.3 \mathrm{~N} / \mathrm{mm}^{2}$ (c); $\rho_{\mathrm{nom}}=190 \mathrm{~kg} / \mathrm{m}^{3}, \mathrm{G}_{\mathrm{sec}}=5.9 \mathrm{~N} / \mathrm{mm}^{2}$ (d)

Abb. 8 Gesamtlast $(\mathrm{kN})$ in Abhängigkeit der Durchbiegung in Feldmitte $(\mathrm{mm})$ von Prüfkörpern in Bauteilgröße und gemäß Tragmodell nach EC-5 für $\rho_{\text {nom }}=110 \mathrm{~kg} / \mathrm{m}^{3}, G_{\mathrm{sec}}=0,7 \mathrm{~N} / \mathrm{mm}^{2}$ (a); $\rho_{\text {nom }}=130 \mathrm{~kg} / \mathrm{m}^{3}, G_{\mathrm{sec}}=1,06 \mathrm{~N} / \mathrm{mm}^{2}$ (b); $\rho_{\text {nom }}=150 \mathrm{~kg} / \mathrm{m}^{3}, G_{\mathrm{sec}}=3,3 \mathrm{~N} / \mathrm{mm}^{2}$ (c); $\rho_{\text {nom }}=190 \mathrm{~kg} / \mathrm{m}^{3}$, $\mathrm{G}_{\mathrm{sec}}=5,9 \mathrm{~N} / \mathrm{mm}^{2}(\mathrm{~d})$

Fig. 9 Total load $(\mathrm{kN})$ versus deflection $(\mathrm{mm})(\mathrm{a})$, and versus total slip at the core $(\mathrm{mm})(\mathrm{b})$, at points B and C (see Fig. 3) for a typical curve (dotted lines), a linear regression (dashed line), and the EC-5 model (continuous line); for $\rho_{\text {nom }}=150$ and $190 \mathrm{~kg} / \mathrm{m}^{3}$.

Abb. 9 Gesamtlast $(\mathrm{kN})$ in Abhängigkeit der Durchbiegung $(\mathrm{mm})(\mathrm{a})$, und in Abhängigkeit der Gesamtschubverformung im Kern (mm) (b), in den Punkten B und C (gem. Abb. 3). Gezeigt sind der gemessene Verlauf (gepunktete Linie), die lineare Regression (gestrichelte Linie) und das EC5 Modell (durchgezogene Linie) für $\rho_{\text {nom }}=150 \mathrm{~kg} / \mathrm{m}^{3}$ und $\rho_{\text {nom }}=190 \mathrm{~kg} / \mathrm{m}^{3}$. 


\section{EJWWP468_source}

Fig. 10 Total load $(\mathrm{kN})$ versus rotation $\left({ }^{\circ}\right)$ at points B (a) and C (b) for a typical curve (dotted lines), a linear regression (dashed line), and the EC-5 model (continuous line); for $\rho_{\text {nom }}=150$ and $190 \mathrm{~kg} / \mathrm{m}^{3}$.

Abb. 10 Gesamtlast $(\mathrm{kN})$ in Abhängigkeit der Verdrehung $\left(^{\circ}\right)$ in den Punkten B (a) und C (b). Gezeigt sind der gemessene Verlauf (gepunktete Linie), die lineare Regression (gestrichelte Linie) und das EC-5 Modell (durchgezogene Linie) für $\rho_{\text {nom }}=150 \mathrm{~kg} / \mathrm{m}^{3}$ und $\rho_{\text {nom }}=190 \mathrm{~kg} / \mathrm{m}^{3}$.

Fig. 11 Failure modes: collapse of the P-IT-110-6 beam.

Abb. 11 Brucharten: Bruch des P-IT-110-6 Trägers. 


\section{TABLES}

Table 1 Equivalent secant shear modulus, $\mathrm{G}_{\mathrm{sec}}$, and shear strength, $\mathrm{f}_{\mathrm{v}, \mathrm{sec}}$, for four different densities

Tabelle 1 Äquivalenter Sekantenschubmodul, $\mathrm{G}_{\mathrm{sec}}$, und Schubfestigkeit, $\mathrm{f}_{\mathrm{v}, \text { sec }}$, für vier unterschiedliche Dichten

\begin{tabular}{lcccc}
\hline $\boldsymbol{\rho}\left[\mathbf{k g} / \mathbf{m}^{\mathbf{3}}\right]$ & $\mathbf{1 1 0}$ & $\mathbf{1 3 0}$ & $\mathbf{1 5 0}$ & $\mathbf{1 9 0}$ \\
\hline $\mathrm{G}_{\mathrm{sec}}\left[\mathrm{N} / \mathrm{mm}^{2}\right]$ & 0.7 & 1.06 & 3.3 & 5.9 \\
$\mathrm{f}_{\mathrm{v}, \mathrm{sec}}\left[\mathrm{N} / \mathrm{mm}^{2}\right]$ & 0.0077 & 0.0133 & 0.054 & 0.096 \\
\hline
\end{tabular}

Table 2 Maximum admissible span ( $\mathrm{m}$ ) for a simply supported (cladding) beam supporting a wind load of $1.2 \mathrm{kN} / \mathrm{m}^{2}$, for both the admissible relative deflection and shear strength at the core

Tabelle 2 Maximal mögliche Spannweite (m) eines einfach gelagerten (Fassaden-) Balkens bei einer Windlast von $1,2 \mathrm{kN} / \mathrm{m}^{2}$, unter Berücksichtigung der zulässigen relativen Durchbiegung und der Schubfestigkeit des Kerns

\begin{tabular}{|c|c|c|c|c|c|c|c|c|c|}
\hline \multirow{2}{*}{$\underset{[\mathrm{kg} / \mathrm{m}]}{\rho} \boldsymbol{\rho}^{3}$} & \multirow{2}{*}{$\begin{array}{c}\mathbf{G}_{\mathrm{sec}}{ }_{2} \\
{\left[\mathrm{~N} / \mathrm{mm}^{2}\right]}\end{array}$} & \multirow{2}{*}{$\begin{array}{l}\text { Total depth } \\
{[\mathrm{mm}]}\end{array}$} & \multirow{2}{*}{$\begin{array}{c}\text { Shear failure at } \\
\text { the core }\end{array}$} & \multicolumn{6}{|c|}{$\begin{array}{c}\text { Failure condition: } \\
\text { admissible relative deflection }\end{array}$} \\
\hline & & & & $1 / 300$ & $1 / 400$ & $1 / 500$ & $1 / 600$ & $1 / 700$ & $1 / 800$ \\
\hline \multirow{4}{*}{110} & \multirow{4}{*}{0.70} & $15+120+15$ & 1.94 & 2.27 & 1.83 & 1.56 & 1.37 & 1.23 & 1.13 \\
\hline & & $15+160+15$ & 2.39 & 2.73 & 2.18 & 1.83 & 1.59 & 1.41 & 1.28 \\
\hline & & $15+200+15$ & 2.86 & 3.20 & 2.54 & 2.12 & 1.83 & 1.61 & 1.45 \\
\hline & & $15+240+15$ & 3.35 & 3.68 & 2.92 & 2.42 & 2.08 & 1.82 & 1.63 \\
\hline \multirow{4}{*}{130} & \multirow{4}{*}{1.06} & $15+120+15$ & 3.11 & 2.89 & 2.36 & 2.00 & 1.75 & 1.56 & 1.41 \\
\hline & & $15+160+15$ & 3.95 & 3.50 & 2.86 & 2.42 & 2.10 & 1.86 & 1.67 \\
\hline & & $15+200+15$ & 4.82 & 4.10 & 3.35 & 2.84 & 2.46 & 2.18 & 1.95 \\
\hline & & $15+240+15$ & 5.69 & 4.68 & 3.84 & 3.26 & 2.82 & 2.49 & 2.23 \\
\hline \multirow{4}{*}{150} & \multirow{4}{*}{3.30} & $15+120+15$ & 12.30 & 4.14 & 3.64 & 3.27 & 2.98 & 2.75 & 2.55 \\
\hline & & $15+160+15$ & 15.80 & 4.96 & 4.36 & 3.92 & 3.58 & 3.31 & 3.08 \\
\hline & & $15+200+15$ & 19.40 & 5.73 & 5.04 & 4.54 & 4.16 & 3.84 & 3.58 \\
\hline & & $15+240+15$ & 23.00 & 6.46 & 5.69 & 5.14 & 4.71 & 4.36 & 4.06 \\
\hline \multirow{4}{*}{190} & \multirow{4}{*}{5.90} & $15+120+15$ & 21.80 & 4.45 & 3.97 & 3.62 & 3.35 & 3.13 & 2.95 \\
\hline & & $15+160+15$ & 28.10 & 5.31 & 4.74 & 4.33 & 4.01 & 3.75 & 3.54 \\
\hline & & $15+200+15$ & 34.50 & 6.11 & 5.46 & 4.99 & 4.62 & 4.33 & 4.09 \\
\hline & & $15+240+15$ & 40.90 & 6.87 & 6.14 & 5.61 & 5.21 & 4.88 & 4.61 \\
\hline
\end{tabular}


EJWWP468_source

Table 3 Relative maximum deflection due to the hygro-thermal variations for WFS with a total depth of a) $(15+100+15) \mathrm{mm}$ and b) $(15+200+15) \mathrm{mm}$

Tabelle 3 Relative maximale Durchbiegung aufgrund hygro-thermischer Beanspruchung für WFS mit einer Dicke von a) $(15+100+15) \mathrm{mm}$ und b) $(15+200+15) \mathrm{mm}$

\begin{tabular}{|c|c|c|c|c|c|c|c|}
\hline \multirow{2}{*}{$\begin{array}{c}\mathbf{z} \\
{[\mathrm{mm}]}\end{array}$} & \multirow{2}{*}{ alpha } & \multirow{2}{*}{ beta } & \multicolumn{5}{|c|}{ Span [m] } \\
\hline & & & 1 & 2 & 3 & 4 & 5 \\
\hline \multirow{4}{*}{115} & 0.02 & 5 & $1 / 920$ & $1 / 460$ & $1 / 307$ & $1 / 230$ & $1 / 184$ \\
\hline & 0.005 & 5 & $1 / 3680$ & $1 / 1840$ & $1 / 1227$ & $1 / 920$ & $1 / 736$ \\
\hline & 0.02 & 15 & $1 / 307$ & $1 / 153$ & $1 / 102$ & $1 / 77$ & $1 / 61$ \\
\hline & 0.005 & 15 & $1 / 1227$ & $1 / 613$ & $1 / 409$ & $1 / 307$ & $1 / 245$ \\
\hline \multirow{4}{*}{215} & 0.02 & 5 & $1 / 1320$ & $1 / 660$ & $1 / 440$ & $1 / 330$ & $1 / 264$ \\
\hline & 0.005 & 5 & $1 / 5280$ & $1 / 2640$ & $1 / 1760$ & $1 / 1320$ & $1 / 1056$ \\
\hline & 0.02 & 15 & $1 / 440$ & $1 / 220$ & $1 / 147$ & $1 / 110$ & $1 / 88$ \\
\hline & 0.005 & 15 & $1 / 1760$ & $1 / 880$ & $1 / 587$ & $1 / 440$ & $1 / 352$ \\
\hline
\end{tabular}

Table $4 \gamma_{i}^{*}$ value at the real scale tested beams ( $\operatorname{span}=3200 \mathrm{~mm}$ ), for the four different densities under study

Tabelle $4 \gamma_{\mathrm{i}}^{*}$ Werte für die Träger in Bauteilgröße (Spannweite $\left.=3200 \mathrm{~mm}\right)$, für vier verschiedene untersuchte Dichten

\begin{tabular}{lcccc}
\hline $\boldsymbol{\rho}$ & $\mathbf{1 1 0}$ & $\mathbf{1 3 0}$ & $\mathbf{1 5 0}$ & $\mathbf{1 9 0}$ \\
{$\left[\mathbf{k g} / \mathbf{m}^{3}\right]$} & & & & \\
\hline$\gamma_{i}^{*}$ & 0.09372 & 0.13540 & 0.32775 & 0.46571 \\
\hline
\end{tabular}




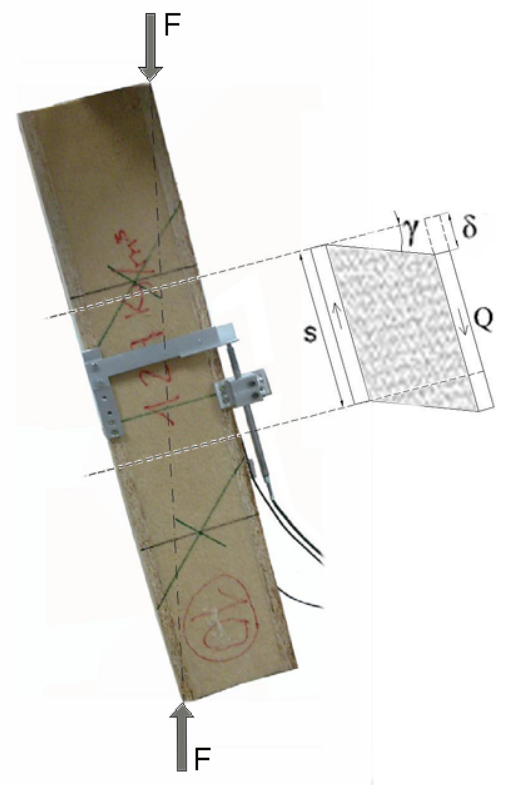




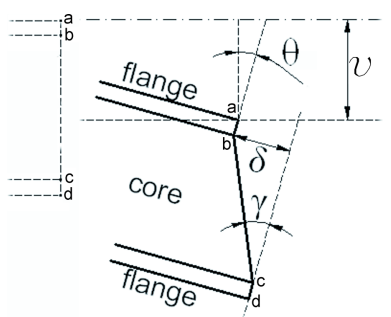




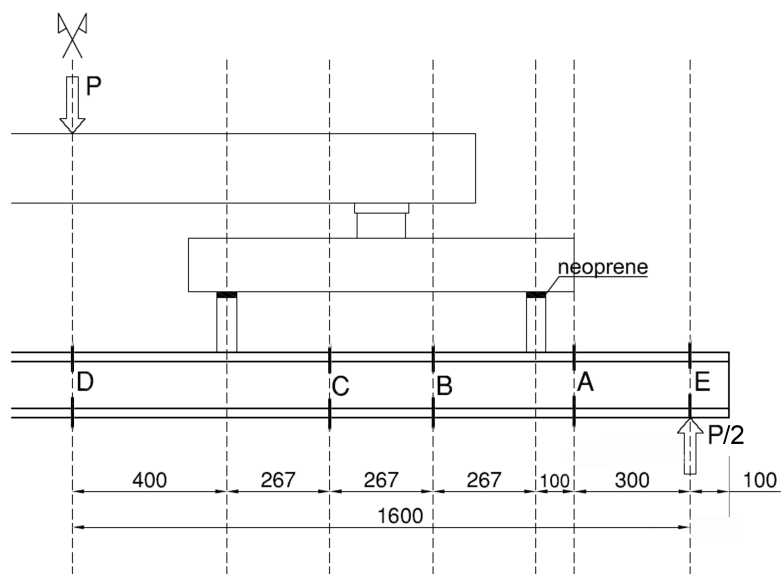




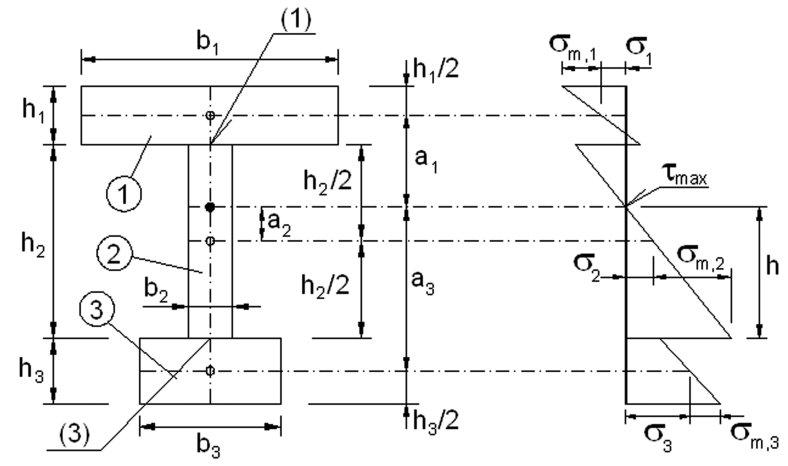



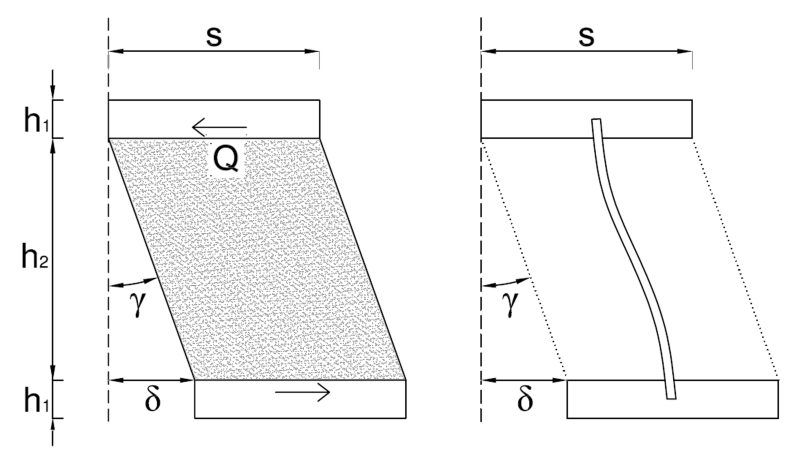


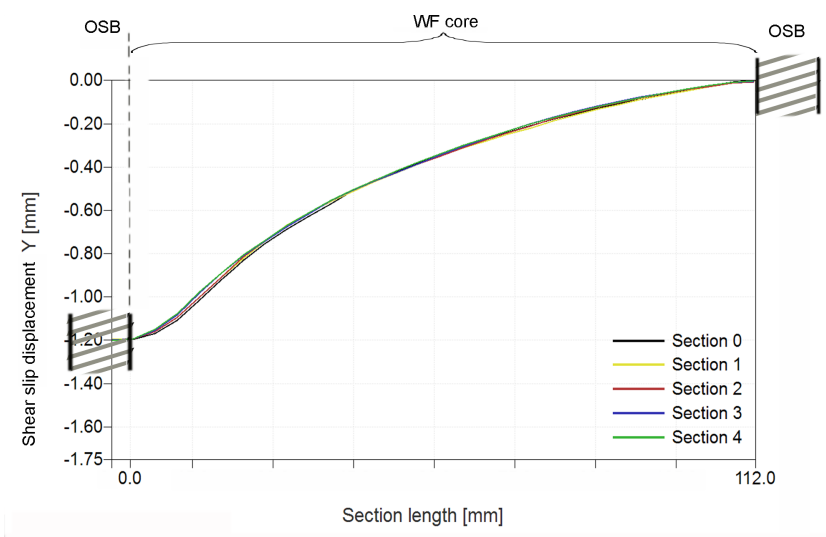




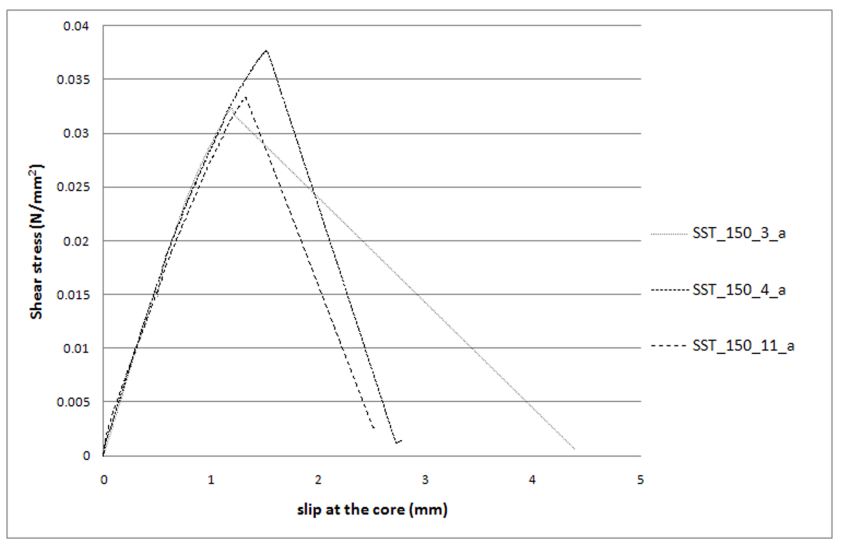



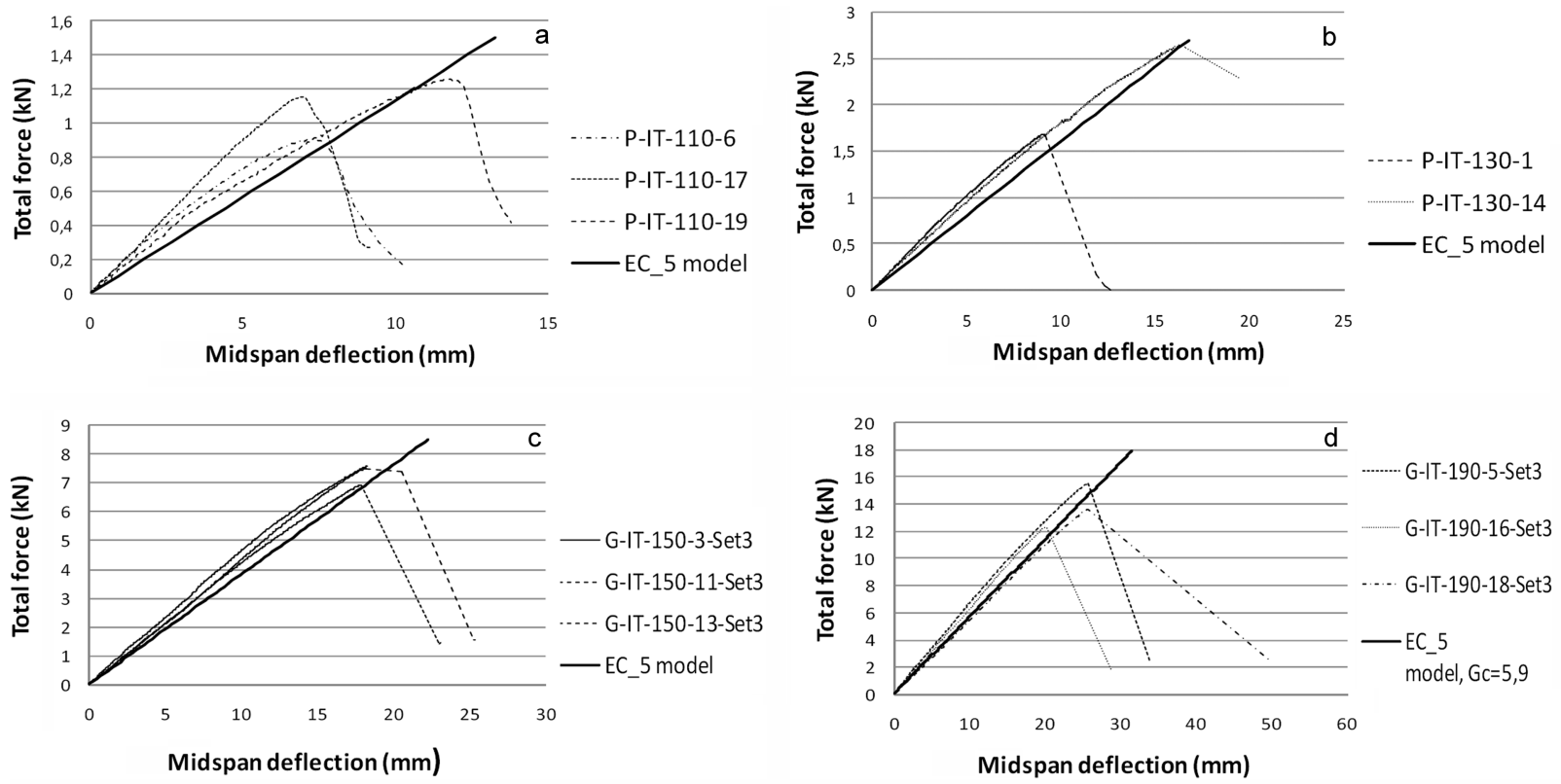

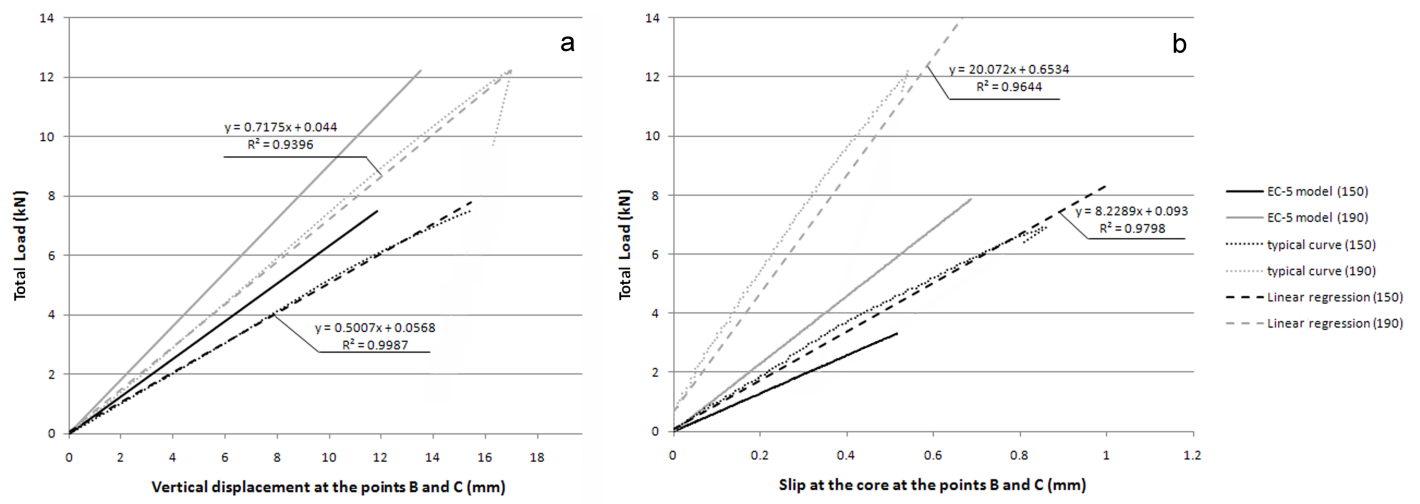

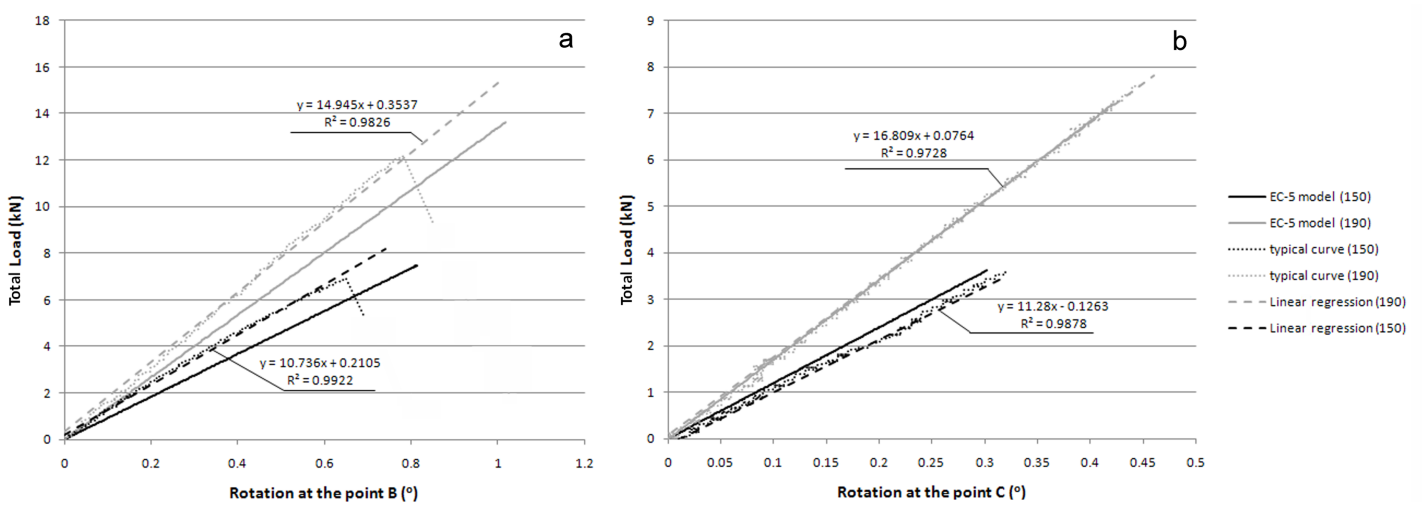


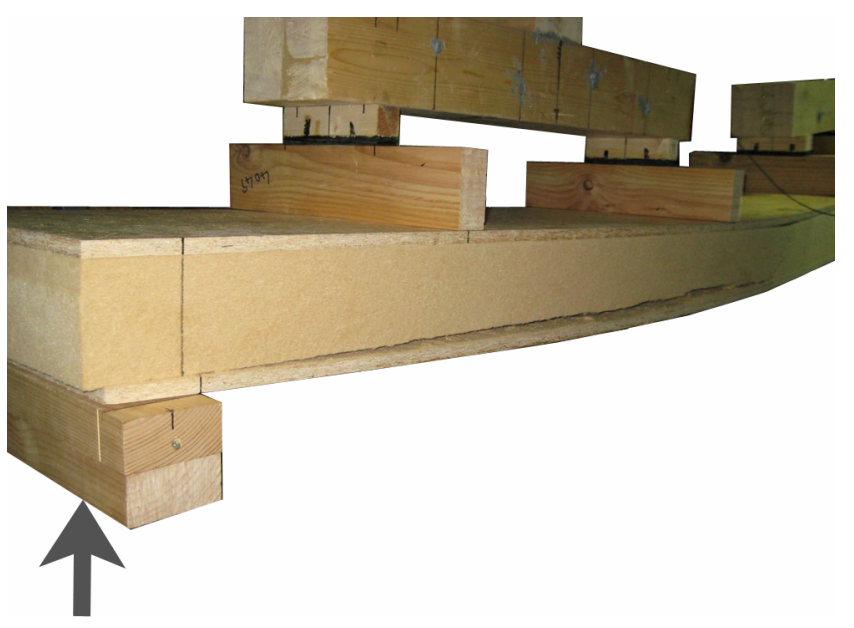

fig11 